\title{
Scoping and Sequencing Educational Resources and Speech Acts: A Unified Design Framework for Learning Objects and Educational Discourse
}

\author{
David A. Wiley and Sandie H. Waters \\ Utah State University, Logan, UT, USA
}

\section{david.wiley@gmail.com sandie.waters@gmail.com}

\begin{abstract}
Instructional design is largely a matter of scope and sequence, and designing instruction with learning objections is no exception. Traditionally, learning objects are considered atomic units of educational content, and designing instruction with learning objects means scoping instructional messages and determining sequences for delivering the messages. We argue that instructional methods that rely heavily on social interaction can be implemented with learning objects when these are understood to be reusable scaffolds for scoping and sequencing what learners say to each other during instructional interactions.
\end{abstract}

Keywords: learning objects, framework, discourse grammar, discourse based learning, educational discourse

\section{Introduction}

Since work on curriculum theory in the 1950's, the dualistic focus of educators and instructional designers has been on the scoping and sequencing of educational content. This concern continues to hold prominence today among even the most advanced instructional technology initiatives. For example, learning objects researchers continue to ask the questions "How big should a learning object be?," and "In what order should we present these learning objects?" (Barritt \& Lewis, 2001; L'Allier, 1998; Merrill, 2000).

Working with learning objects creates concerns over and above the traditional pair of scope and sequence. Wiley claimed that learning objects users need at least the following three components in an instructional design framework using learning objects:

1. A taxonomy of learning object types which provides support for making scoping decisions,

Material published as part of this journal, either on-line or in print, is copyrighted by the publisher of the Informing Science Journal. Permission to make digital or paper copy of part or all of these works for personal or classroom use is granted without fee provided that the copies are not made or distributed for profit or commercial advantage AND that copies 1) bear this notice in full and 2) give the full citation on the first page. It is permissible to abstract these works so long as credit is given. To copy in all other cases or to republish or to post on a server or to redistribute to lists requires specific permission and payment of a fee. Contact Publisher@ijklo.org to request redistribution permission.
2. A structured approach to the sequencing of educational content, and

3. A crosswalk relating the specific taxonomy of types to the specific sequencing methodology (Wiley, 2000).

Ideally any specific choice for either the scoping or sequencing components could be replaced by another choice of the same component type. For exam- 
ple, a simple to complex sequencing strategy (e.g., Reigeluth's Elaboration Theory) could be replaced by a more complex approach (e.g., van Merrienboer's Four Component Instructional Design model) and still be linked to the same scoping mechanism (Reigeluth, 1992, 1999a; Reigeluth \& Darwazeh, 1982; Reigeluth, Merrill, Wilson, \& Spiller, 1980; van Merriënboer, 1997).

Perhaps the simplest example of such a taxonomy of learning object types connected to a sequencing structure is Merrill's First Principles of Instructional Design (FPID) Model (Merrill, 2001). Learning object types for FPID can be defined by instructional function; for example, one learning object would present the real-world problem the learner will be engaging and another would provide opportunities for practice and provide feedback. Figure 1 shows the simplest version of learning objects-based instruction drawing on FPID for a taxonomy of types of objects and what sequences they should be used in.

\section{Content Packages Sequenced According to Simple Merrill FPID Model}

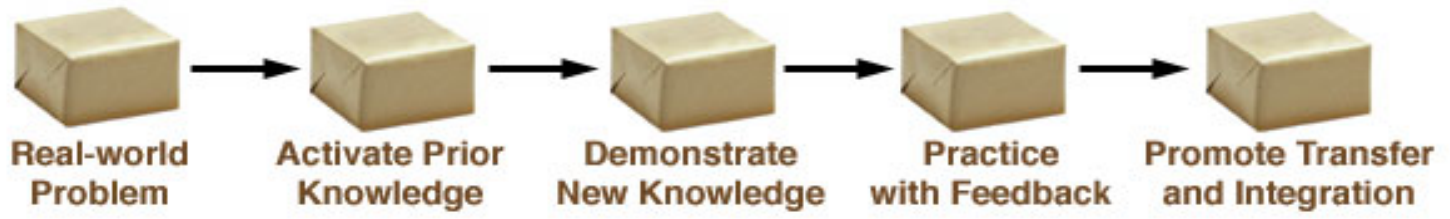

Figure 1. Learning objects scoped and sequenced according to Merrill's FPID (2001).

Several individuals and corporations are pursuing robust methods for defining scope and sequencing standards for learning objects, which will enable automated individualization of computerbased instruction. Products like Learn eXact (Giunti Interactive Labs, 2003) and Evolution (OutStart, 2003) provide previews of what this technology may become. However, comparatively little attention is being paid to developing computer-mediated social structures which are capable of supporting deeper, richer learning (Wiley \& Edwards, 2002).

Learning objects-based instruction is frequently criticized as being limited to use within behavioral and cognitive paradigms. The main claim of this paper is that the same three-component framework that facilitates the design of content for use in these traditions can be used to design and build learning objects that support highly social modes of instruction.

\section{The Scope and Sequencing of Speech Acts in Educational Discourse}

Effective discourse often follows patterns, occasionally called "discourse grammars." A variety of discourse grammars exist, for example, IBIS (Kunz \& Rittel, 1970), Toulmin's Model of Argument (Toulmin, 1959), and Progressive Inquiry (Hakkarainen, 1998). What each of these models has in common is a taxonomy of speech acts or description of the types of statements that can be made, and sequences in which these types should occur. Figure 2 shows Toulmin's Model of Argument as a sequenced series of speech acts, with types of speech acts and sequencing information provided by the model.

Many of these models were developed with a grounded theory approach; that is, they are each generalizations of analyses of successful group interactions. These descriptions of successful ac- 
tivity may be turned into prescriptions for structures likely to facilitate later successful engagements in similar activities. Such prescriptions would be probabilistic in Reigeluth's sense (Reigeluth, 1999a, 1999b, 1999c).

\section{Speech Acts Sequenced According to Toulmin's Model of Argument}

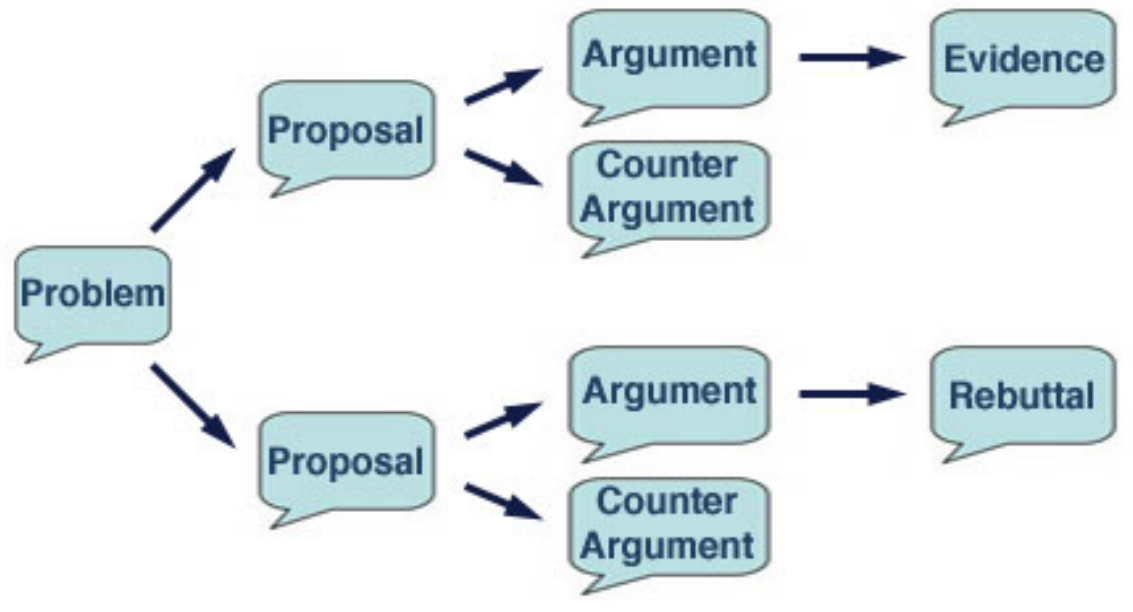

Figure 2. Toulmin's Model of Argument as a sequenced series of speech acts (1959).

Groupware systems have been designed and developed specifically to support learners interacting according to such structures, such as Belvedere, D3E, Compendium, and Zeno. More recently, Fle3 has appeared as an open and extensible system which, while providing support for two discourse grammars called "Progressive Inquiry" and "Design Thinking Types," scaffolds its grammars in a relatively neutral manner so that additional grammars can be used within the system. Fle3 also provides authoring capabilities supporting the deployment of new discourse grammars. Figure 3 demonstrates Fle3's scaffolding of the discourse process (2003).

Fle3 scaffolds the posting of new messages in the discussion by:

- Providing a controlled list of message types from which the user must select before replying or creating a message,

- Providing a "message stub" in the Message Body box to cue the student to only enter specific types of messages within the box, and

- Using the colored Flea Asks box to give just-in-time support to the student with regard to appropriate kinds of content for this message type. 


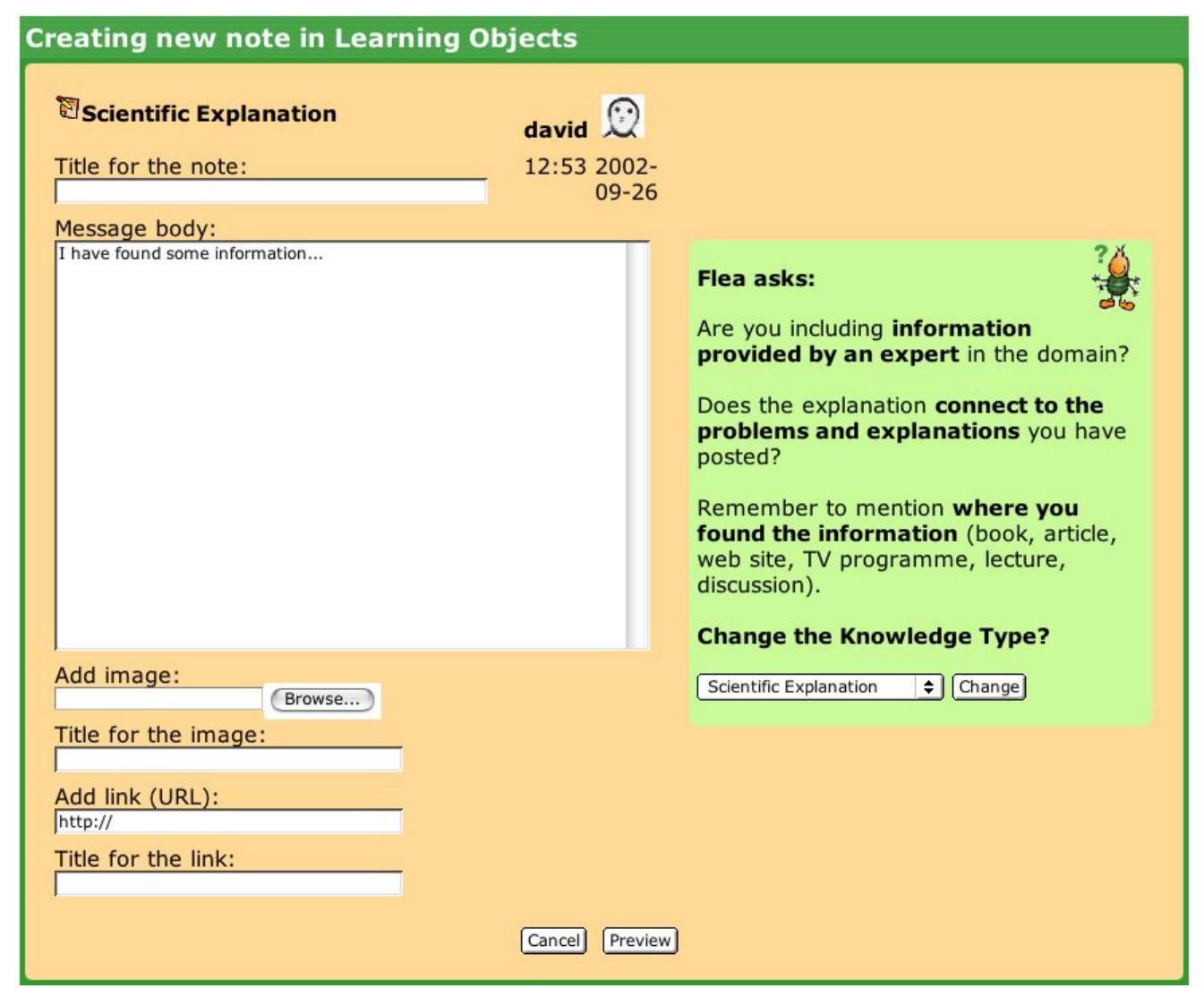

Figure 3. Fle3's scaffolding of individual speech acts within a broader discourse (2003).

One can imagine supporting arbitrary discourse grammars within a collaborative environment, which can scaffold learners' engagement in such conversations. For example, Gunawardena, Lowe, \& Anderson (1997) identified a five phase pattern for the generation of new knowledge and understanding in groups. Their analysis model contains a set of codes for analyzing transcripts of learner interactions. The summary in Table 1 is adapted from ALNresearch.org, and could easily fit into the scaffolds provided by Fle3 or a similar system. 
Table 1: Gunawardena, Lowe, \& Anderson's interaction model for collaborative knowledge building

\section{Phase I: Sharing/Comparing of Information}

1. A statement or observation or opinion

2. A statement of agreement from one or more participants

3. Corroborating examples provided by one or more participants

4. Asking and answering questions to clarify details of statements

5. Definition, description, or identification of a problem

Phase II: The Discovery and Exploration of Dissonance or Inconsistency among Ideas, Concepts, or Statements

1. Identifying and stating areas of disagreement

2. Asking and answering questions to clarify the source and extent of disagreement

3. Restating the participants' position, and possibly advancing arguments or considerations in its support by references to the participants' experience, literature, formal data collected, or proposal of relevant metaphor or analogy to illustrate point of view

\section{Phase III: Negotiation of Meaning/Co-Construction of Knowledge}

1. Negotiation or clarification of the meaning of terms

2. Negotiation of the relative weight to be assigned to types of arguments

3. Identification of areas of agreement or overlap among conflicting concepts

4. Proposal and negotiation of new statements embodying compromise, coconstruction

5. Proposal of integrating or accommodating metaphors or analogies

Phase IV: Testing and Modification of Proposed Synthesis or Co-Construction

1. Testing the proposed synthesis against "received fact" as shared by the participants and/or their culture

2. Testing against existing cognitive schema

3. Testing against personal experience

4. Testing against formal data collected

5. Testing against contradictory testimony in the literature

Phase V: Agreement Statement(s)/Applications of Newly-Constructed Meaning

1. Summarization of agreement

2. Applications of new knowledge

3. Metacognitive statements by the participants illustrating their understanding and that their knowledge or ways of thinking (cognitive schema) have changed as a result of the conference interaction 


\section{Fusing Roles and Responsibilities}

A great deal of work is merging the study of discourse analysis with the idea of learning objects and sequenced speech acts. The claim of this paper is that the same three part framework - taxonomy plus sequencing rules plus connection between the two - can support a technological implementation of both learning objects-based and discourse-based technology-mediated learning. A greater autonomy is given to the participant once a series of scaffolds are placed within the instructional event. However, the role of the players in the instructional design and development process changes somewhat as demonstrated in Table 2.

Table 2: Change in Roles from Content-based to Discourse-based learning

\begin{tabular}{|c|c|c|}
\hline & $\begin{array}{l}\text { Technology Mediated, } \\
\text { Content-based }\end{array}$ & $\begin{array}{l}\text { Technology Mediated, } \\
\text { Discourse-based }\end{array}$ \\
\hline $\begin{array}{l}\text { Instructional } \\
\text { Theorist }\end{array}$ & $\begin{array}{l}\text { - Constructs taxonomies and } \\
\text { groups sequencing rules } \\
\text { - Connects taxonomies to sequenc- } \\
\text { ing rules }\end{array}$ & $\begin{array}{l}\text { - Constructs taxonomies and } \\
\text { groups sequencing rules } \\
\text { - Connects taxonomies to sequenc- } \\
\text { ing rules }\end{array}$ \\
\hline $\begin{array}{l}\text { Instructional De- } \\
\text { signer }\end{array}$ & $\begin{array}{l}\text { - Selects taxonomy-sequencing } \\
\text { combination appropriate for cur- } \\
\text { rent learning need } \\
\text { - Specs out implementation }\end{array}$ & $\begin{array}{l}\text { Selects taxonomy-sequencing } \\
\text { combination appropriate for cur- } \\
\text { rent learning need } \\
\text { - Specs out implementation }\end{array}$ \\
\hline $\begin{array}{l}\text { Instructional De- } \\
\text { veloper }\end{array}$ & $\begin{array}{l}\text { - Creates technology implementa- } \\
\text { tion of type containers and pre- } \\
\text { sequences according to designer's } \\
\text { specs } \\
\text { Creates information of appro- } \\
\text { priate types (learning objects) } \\
\text { within typed containers (in- } \\
\text { structional sequence) }\end{array}$ & $\begin{array}{l}\text { Creates technology implementa- } \\
\text { tion of type containers and pre- } \\
\text { sequences according to de- } \\
\text { signer's specs }\end{array}$ \\
\hline Learner & - Interacts with container contents & $\begin{array}{l}\text { - Creates information of appro- } \\
\text { priate types (speech acts) } \\
\text { within typed containers (dis- } \\
\text { course grammars) } \\
\text { - Interacts with container contents }\end{array}$ \\
\hline
\end{tabular}

Implied in Table 2 is that when dealing with discourse grammars in the unified framework described above, responsibility for actually plugging content into an instructional structure is passed down from the designer to the learner. There is absolutely nothing new in suggesting this shift in responsibility; Carr-Chelman has long been calling for the fusing of roles into "user-designers" or "learner-designers" (Carr-Chellman, 1995, 2000).

\section{Concluding Remarks}

Traditionally instructional designers have been concerned with scoping and sequencing content. Learners would then (hopefully) engage the content in the predicted manner, after which there would be some chance of learning occurring. However, the nomenclature of "instructional de- 
sign" may be too rough grained. If the model described herein is adopted and utilized, we may need to distinguish between "instructional content design" and "instructional discourse design." As research continues to demonstrate the importance of social interaction in certain types of learning outcomes, and as calls for learner emancipation and empowerment through dialogue continue (cf. Freire or Habermas), we hope to see the day when instructional discourse design becomes well developed sub-discipline of instructional design, and balanced instructional approach mixing well-designed content and well-designed interactions among learners are common.

\section{References}

Barritt, C., \& Lewis, D. (2001). Reusable learning object strategy. Retrieved July 23, 2001, from http://www.cisco.com/warp/public/10/wwtraining/elearning/learn/whitepaper docs/rlo strategy v3$\underline{1 . p d f}$

Carr-Chellman, A. A. (1995). Power, expertism, and the practice of instructional design: Empowering the users. In G. J. Anglin (Ed.), Instructional technology: Past, present and future (2nd ed.). Englewood, CO: Libraries Unlimited.

Carr-Chellman, A. A. (2000). Power, expertism, and the practice of instructional design: Empowering the users. Paper presented at the Annual Conference of the Association of Educational Communications and Technology, Denver, CO.

Fle3. (2003). Fle3 > Future Learning Environment. Retrieved December 10, 2003, from http://fle3.uiah.fi/

Giunti Interactive Labs. (2003). the X learning Company. Retrieved December 10, 2003, from http://www.giuntilabs.com/

Gunawardena, C. N., Lowe, C. A., \& Anderson, T. (1997). Analysis of a global online debate and the development of an interaction model for examining social construction of knowledge in computer conferencing. Journal of Educational Computing Research, 17(4), 397-431.

Hakkarainen, K. (1998). Epistemology of inquiry and computer-supported collaborative learning. Unpublished Doctoral Dissertation, University of Toronto, Canada.

Kunz, W., \& Rittel, H. (1970). Issues as elements of information systems (Working Paper 131). Center for Planning and Development Research, The University of California at Berkeley, CA.

L'Allier, J. J. (1998). NETg's precision skilling: The linking of occupational skills descriptors to training interventions. Retrieved April 2, 2001, from http://www.netg.com/research/pskillpaper.htm

Merrill, M. D. (2000). Knowledge objects and mental models. Retrieved July 23, 2001, from http://reusability.org/read/chapters/merrill.doc

Merrill, M. D. (2001). First principles of instruction. Retrieved September 30, 2003, from http://www.id2.usu.edu/Papers/5FirstPrinciples.PDF

OutStart. (2003). OutStart: Enabling Enterprise Learning. Retrieved December 10, 2003, from http://www.outstart.com/default.asp

Reigeluth, C. M. (1992). Elaborating the elaboration theory. Educational Technology Research \& Development, 40(3).

Reigeluth, C. M. (1999a). The elaboration theory: Guidance for scope and sequence decisions. In C. M. Reigeluth (Ed.), Instructional-design theories and models: A new paradigm of instructional theory (Vol. 2, pp. 425-453). Wahwah, NJ: Lawrence Erlbaum Associates, Inc.

Reigeluth, C. M. (1999b). What is instructional-design theory and how is it changing? In C. M. Reigeluth (Ed.), Instructional-design theories and models: A new paradigm of instructional theory (Vol. 2, pp. 529). Mahwah, NJ: Lawrence Erlbaum Associates, Inc.

Reigeluth, C. M. (Ed.). (1999c). Instructional design theories and models: A new paradigm of instructional technology (Vol. 2). Mahwah, NJ: Lawrence Erlbaum Associates, Inc. 
Reigeluth, C. M., \& Darwazeh, A. N. (1982). The elaboration theory's procedure for designing instruction: A conceptual approach. Journal of Instructional Development, 5(3), 22-32.

Reigeluth, C. M., Merrill, M. D., Wilson, B. G., \& Spiller, R. T. (1980). The elaboration theory of instruction: A model for structuring instruction. Instructional Science, 9(3), 195-219.

Toulmin, S. (1959). The uses of argument. Cambridge, MA: Cambridge University Press.

van Merriënboer, J. J. G. (1997). Training complex cognitive skills: A four-component instructional design model for technical training. Englewood Cliffs, NJ: Educational Technology Publications.

Wiley, D. A. (2000). Learning object design and sequencing theory: Unpublished doctoral dissertation, Brigham Young University.

Wiley, D. A., \& Edwards, E. K. (2002). Online self-organizing social systems: The decentralized future of online learning. Quarterly Review of Distance Education.

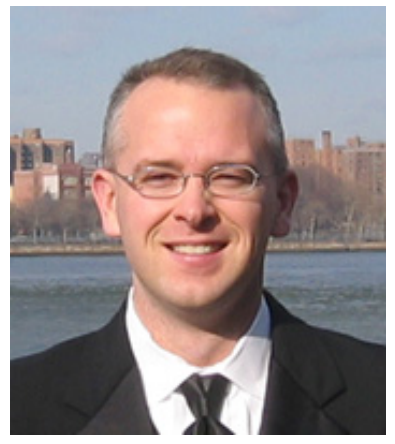

\section{Biography}

Dr. David Wiley is Director of the Center for Open and Sustainable Learning at Utah State University and Assistant Professor in the Department of Instructional Technology there. His primary research interest is utilizing technology to provide greater access to educational opportunities to individuals who have been underserved for whatever reason. He holds a PhD in Instructional Psychology and Technology from Brigham Young University and a BFA in Vocal Performance from Marshall University.

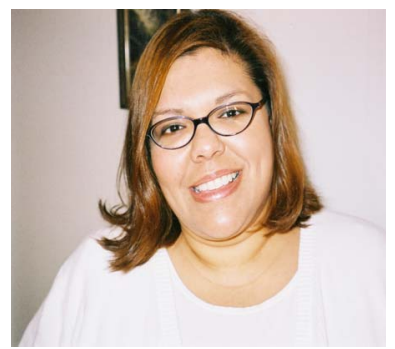

Sandie H. Waters is a Ph.D. candidate in Instructional Technology at Utah State University. Her current research interests include student experiences' and attitudes' towards ACMC tools in bounded online learning communities, discourse analysis, and design languages and notational systems. Sandie is available by at sandie.waters@gmail.com or mail through the Department of Instructional Technology, Utah State University, Logan, UT 84322-2830. 